International Research Journal of Management, IT \& Social Sciences
Available online at https://sloap.org/journals/index.php/irjmis/
Vol. 7 No. 1, January 2020, pages: 169-176
ISSN: 2395-7492
https://doi.org/10.21744/irjmis.v7n1.831

\title{
Implementation of Good Government Governance, Intellectual Intelligence, Emotional, and Spiritual Intelligence in Managerial Performance of Village Government Management
}

\begin{tabular}{|c|c|}
\hline & $\begin{array}{r}\text { I. G. A. M. Asri Dwija Putri } \\
\text { Ni Gusti Putu Wirawati } \\
{ }^{\text {b }}\end{array}$ \\
\hline Article history: & Abstract \\
\hline $\begin{array}{l}\text { Submitted: } 18 \text { November } 2019 \\
\text { Revised: } 27 \text { December } 2019 \\
\text { Accepted: } 12 \text { January } 2020\end{array}$ & $\begin{array}{l}\text { This research aims to describe the implementation of good government } \\
\text { governance in Badung Regency Village Government, to examine the effect of } \\
\text { good government governance, intellectual intelligence, emotional intelligence, } \\
\text { and spiritual intelligence on the managerial performance of village government } \\
\text { officials in Badung Regency. This research was conducted in Badung Regency }\end{array}$ \\
\hline $\begin{array}{l}\text { Keywords: } \\
\text { emotional intelligence; } \\
\text { good governance; } \\
\text { intellectual intelligence; } \\
\text { managerial performance; } \\
\text { spiritual intelligence; }\end{array}$ & $\begin{array}{l}\text { with } 230 \text { respondents from the village government officials. Determination of } \\
\text { the sample using non-probability sampling with a saturation sampling } \\
\text { technique. Data collection methods were carried out using questionnaires and } \\
\text { data analysis techniques using multiple linear regression analysis. The results } \\
\text { of this research indicate that the variables of Good Governance, intellectual } \\
\text { intelligence, emotional intelligence, and spiritual intelligence have a positive } \\
\text { effect on the Managerial Performance of Village Government Officials in } \\
\text { Badung Regency. }\end{array}$ \\
\hline
\end{tabular}

International research journal of management, IT and social sciences (C) 2020. This is an open access article under the CC BY-NC-ND license (https://creativecommons.org/licenses/by-nc-nd/4.0/).

Corresponding author:

I. G. A. M. Asri Dwija Putri,

Faculty of Economics and Business, Udayana University, Denpasar, Indonesia.

Phone: 0812395747

Email address:igamasri@yahoo.com

adayana University, Denpasar, Indonesia

Udayana University, Denpasar, Indonesia 


\section{Introduction}

Since the enactment of Law of the Republic of Indonesia Number 6 of 2014 concerning Villages, mandates the granting of village funds whose funding is directly from the APBN. The village head as the head of the village government management has an important role in managing village funds in realizing community welfare. The village head as the organizer of the village government management is required to have a reliable managerial performance. The rise of corruption cases that occurred in the government both central, regional and village governments. According to media reports bali.antaranews.com "recorded corruption cases in around 89 percent of corruption cases occurred in the regional government, namely at the provincial level (20 cases), districts (170 cases), cities (48 cases) and villages (104 cases)". Based on national.kompas.com "recorded at least 181 cases of corruption in village funds with 184 suspected corruption and a loss of Rp 40.6 billion," ICW researcher Egi Primayogha said in a written statement Wednesday (11/21/2018). Although based on the BPKP report for the 9 regencies in the Bali region, they have received a Fair Opinion without Exception (WTP) opinion, but there are still cases of corruption involving village heads also occurring in Bali such as the case for Baha village, Badung district in the 2015-2016 period.

Managerial performance is one of the factors that can be used to measure improvement in organizational effectiveness. The managerial performance of village government management is a description of the level of achievement of goals or objectives as a translation of the vision, mission, and strategy of village government agencies that indicate the level of success or failure of the implementation of activities in accordance with the main tasks and functions of the village government apparatus. In improving managerial performance, good governance is needed. Mardiasmo (2004), explains Good Governance as a way of managing public affairs and governance covering all mechanisms, processes, and institutions where citizens and community groups express their interests, exercise legal rights, fulfill obligations and bridge the differences between them. In addition, it is undeniable that the success and success of a person or an organization are not only determined by Intellectual Intelligence (IQ), but the success and success or performance of a person is also influenced by Emotional Intelligence (EQ) and Spiritual Intelligence (SQ). For this reason, Intellectual Intelligence (IQ), Emotional Intelligence (EQ) and Spiritual Intelligence (SQ) owned by village government officials must be explored and developed, so it is expected to have a positive impact on the performance of village government (Yanti \& Dwirandra, 2019).

In this study related to the problems that exist researchers used the factors of applying Good Government Governance (GGG), intellectual intelligence, emotional intelligence, and spiritual intelligence in seeing their effects on the managerial performance of village government management in Badung Regency because these factors are currently becoming important issues to find solutions to improve performance on an ongoing basis. The purpose of this study is to describe the implementation of Good Government Governance in Badung Regency Village Government, proving the influence of good government governance, intellectual intelligence, emotional intelligence, and spiritual intelligence on the managerial performance of Village Government Management in Badung Regency. This research is expected to provide insight into agency theory and stewardship theory in explaining the influence of good government governance, intellectual intelligence, emotional intelligence, and spiritual intelligence on the managerial performance of village government management. It is also expected that this research can be a reference for further research and can contribute thoughts on improving the managerial performance of Village Government Management in Badung Regency. Based on the theoretical basis and empirical studies from previous research, the conceptual framework used in this study can be seen in the following figure.

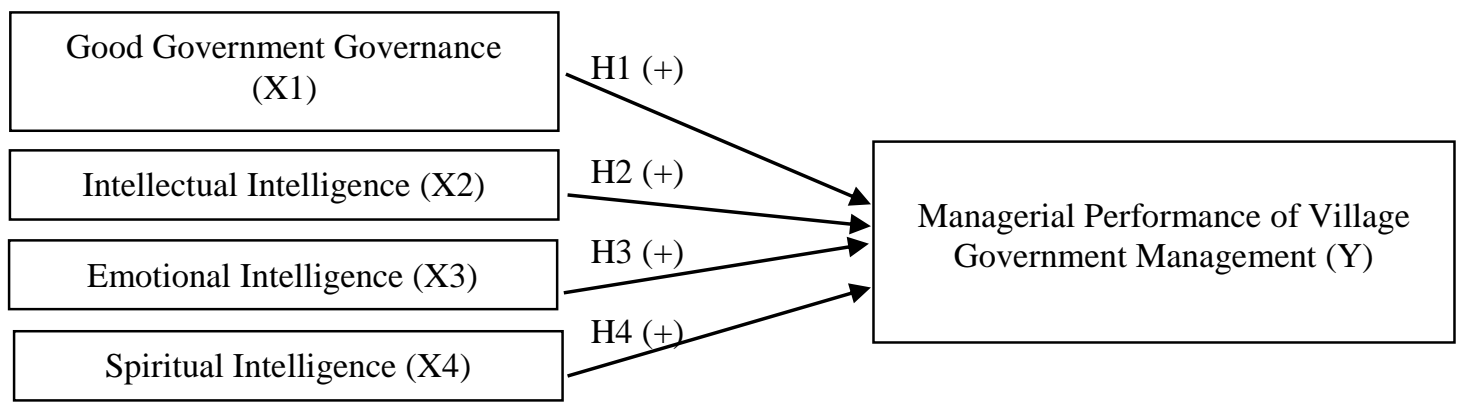

Figure 1. Conceptual framework 
In regional government agencies, the relationship between principals and agents is the agent carrying out planning, implementation, and reporting related to the regional budget while the principal has a role in carrying out supervision (Hasanah \& Suartana, 2014; Dewi \& Ramantha, 2019). In the agency relationship, the government as an agent must carry out what is in the interests of users of government financial information as a principal (Rosalin \& Kawedar, 2011). Stewardship theory is a depiction of the condition of managers who are motivated by the main outcome target of organizational interests rather than motivated against their personal interests (Donaldson \& Davis, 1991). Stewardship theory has a psychological and sociological basis that has been designed in which the management as a steward is motivated to act in accordance with the wishes of the principal, in addition to this steward behavior will not leave the organization because the steward tries to achieve its organizational goals (Riyadi \& Yulianto, 2014). In line with the stewardship theory, the application of Good Government Governance (GGG) in an organization will be able to minimize the opportunistic nature of management so that it has an impact on improving organizational performance. In the relationship or contract, agency problems occur due to the information asymmetry between the agent and the principal. One way to monitor contract issues and limit opportunistic behavior in management is to implement Good Government Governance (GGG) (Widasari \& Putri, 2018).

Putri (2012), in her research, that Good Corporate Governance (GCG) and good corporate culture (GCC) will be supporting factors for achieving good performance. Fimela (2011), concluded that Good Governance has a positive effect on public sector performance. The results showed that the better the Good Governance, the better the performance of local governments, otherwise bad Good Governance results in poor performance of local governments as well. Based on these explanations, the hypothesized relationship between the applications of good governance to managerial performance can be drawn as follows:

H1: Good government governance has a positive effect on managerial performance.

According to Robbins \& Judge (2008), intellectual intelligence is the ability needed to perform various activities of thinking, solving problems and being able to infer and manage information into reality. Mulyadi (2014), explains the profession is a work environment in society that requires the requirements of skills and authority. The ability of village government officials can be measured by intellectual intelligence (Rubiyanto, 2010). A worker who has a high IQ is expected to produce better performance than those who have a lower IQ. Someone who has a high IQ more easily absorbs the knowledge provided so that his ability to find and solve problems related to his work will be better. If a village government organizer has high intellectual intelligence, one can understand and apply the knowledge he has gained. Jafridin et al. (2006), states that if an employee has high intellectual intelligence, the performance that will be owned will be high, it is evident that intellectual intelligence still has an important role in improving employee performance. Based on these explanations, the hypothesized relationship between the applications of work motivation to managerial performance can be drawn as follows:

H2: intellectual intelligence has a positive effect on managerial performance.

Emotional intelligence is the intelligence in using emotions in accordance with the desires and abilities in controlling emotions so that they can have a positive impact. This is as stated by Patton (1998), that the effective use of emotions will be able to achieve goals in building productive relationships in achieving work success. Performance is not only seen by intellectual factors but also determined by emotional factors. Someone who can control his emotions well will be able to produce good performance too. Research conducted by Yenti \& Machasin (2014), states that emotional intelligence has a significant effect on employee performance at R.S Pekan Baru. Based on this, the hypothesis can be formulated as follows:

H3: Emotional intelligence has a positive effect on managerial performance.

Spiritual intelligence teaches a person to express and give meaning to each of his actions, so if you want to display good performance, spiritual intelligence is needed (Munir, 2000). Through this spiritual intelligence, the village government management can play its moral awareness to overcome the conflicts that occur within it. A person who has good spiritual intelligence is able to synergize all components of his intelligence and can achieve good performance as well.

Research Widiani et al. (2019) states that spiritual intelligence positively and significantly influences employee performance. Based on this, the hypothesis can be formulated as follows:

H4: Spiritual intelligence has a positive effect on managerial performance

Putri, I. G. A. M. A. D., \& Wirawati, N. G. P. (2020). Implementation of good government governance, intellectual intelligence, emotional, and spiritual intelligence in managerial performance of village government management. International Research Journal of Management, IT and Social Sciences, 7(1), 169-176. https://doi.org/10.21744/irjmis.v7n1.831 


\section{Materials and Methods}

This research was conducted in Badung Regency, namely in 46 official villages in Badung Regency. This location was chosen because based on the existing problems, it is important to maintain the good name of Government Management in Badung Regency. The population in this study is the village government apparatus in 46 villages throughout Badung Regency. This study took a sample of 5 samples in each village studied. The sampling method used in this study is nonprobability sampling with a saturated sampling technique. In this research, the validity and reliability testing of the questionnaire was first carried out. Then classic assumption tests and data analysis techniques will be performed. The data analysis technique used in this study is multiple linear regression analysis because it consists of more than two independent variables. The equation of the multiple linear regression equation used in this study is as follows:

$$
\mathrm{Y}=\alpha+\beta_{1} \mathrm{X}_{1}+\beta_{2} \mathrm{X}_{2}+\beta_{3} \mathrm{X}_{3}+\beta_{4} \mathrm{X}_{4}+\varepsilon
$$

Information:

$\mathrm{Y}=$ managerial performance

$\alpha=$ constant

$\beta 1-\beta 4=$ regression coefficient

$\mathrm{X} 1$ = Good Government Governance

$\mathrm{X} 2$ = intellectual intelligence

$\mathrm{X} 3=$ emotional intelligence

$\mathrm{X} 4$ = spiritual intelligence

$\varepsilon=$ error

\section{Results and Discussions}

The validity test is measured by the $\mathrm{r}$ Pearson correlation. The results of the correlation rationale for good government governance variables are $0.538-0.635$, the intellectual intelligence variable is $0.708-0.704$, the emotional intelligence variable is $0.763-0.848$, spiritual intelligence variable is $0.731-0.756$, and managerial performance variable is 0.588 0.731. These results indicate the Pearson correlation value is greater than 0.30 so that the five variables in the questionnaire are declared valid. Reliability testing is measured by the Cronbach's Alpha coefficient. The results show that the Cronbach's alpha value of each variable has a value greater than 0.70 , so that the statements in the research questionnaire are declared reliable. The following results from descriptive statistics can be seen in Table 1 .

Table 1

Descriptive statistics results

\begin{tabular}{llllll}
\hline Variable & $\mathrm{N}$ & Minimum & Maximum & Mean & Std. Deviation \\
\hline Good Government Governance $\left(\mathrm{X}_{1}\right)$ & 230 & 52,00 & 75,00 & 64,95 & 5,279 \\
Intellectual Intelligence $\left(\mathrm{X}_{2}\right)$ & 230 & 22,00 & 35,00 & 29,04 & 2,865 \\
Emotional Intelligence $\left(\mathrm{X}_{3}\right)$ & 230 & 41,00 & 55,00 & 49,38 & 4,483 \\
Spiritual Intelligence $\left(\mathrm{X}_{4}\right)$ & 230 & 21,00 & 30,00 & 26,76 & 2,403 \\
Managerial Peformance $(\mathrm{Y})$ & 230 & 34,00 & 50,00 & 42,14 & 3,860 \\
\hline Sechen
\end{tabular}

Secondary Data, 2019

Based on Table 1, the lowest value of respondents 'answers for Good Government Governance (GGG) variables is 52 and the highest value is 75. The average value of respondents' answers for Good Government Governance (GGG) variables is 64.95, this means that the answers respondents are greater than 64.95, including those who have high Good Government Governance (GGG). If the total score of the answer is less than 64.95, then it includes the respondents who have low Good Government Governance (GGG) with a deviation of 5.279. Based on Table 1 obtained the lowest value of the total score of respondents answers for the intellectual intelligence variable of 22 and the highest value of 35 . The average value of the total score of respondents' answers for the intellectual intelligence variable is 29.04 , this means that if the number of respondents score is greater than 29.04, including respondents who have high intellectual 
intelligence. If the total score of the answer is less than 29.04, it includes respondents who have low intellectual intelligence with a deviation of 2.865 .

Based on Table 1 obtained the lowest value of the total score of respondents' answers for the emotional intelligence variable by 41 and the highest value by 55. The average value of the total score of respondents' answers for the emotional intelligence variable was 49.38 which means that if the total score of respondents' answers was greater than 49.38, including respondents who have high emotional intelligence. If the total score of the answers is less than 49.38, it includes respondents who have low emotional intelligence with a deviation of 4.483. Based on Table 1 obtained the lowest value of the total score of respondents 'answers for the spiritual intelligence variable of 21 and the highest value of 30. The average value of the total score of respondents' answers for spiritual intelligence variables is 26.76 this means that if the number of respondents score is greater than 26.76, it includes respondents who have high spiritual intelligence. If the total score of the answer is less than 26.76, then it includes the respondents who have low spiritual intelligence with a deviation of 2.403. Based on Table 1 obtained the lowest value of the total score of respondents' answers for the performance variable of 34 and the highest value of 50. The average value of the total score of respondents' answers for managerial performance variables is 41.14 this means that if the total score of respondents' answers is greater than 41,14 then including respondents who have high performance. If the total score of the answers is less than 41.14, it includes respondents who have a low performance with a deviation of 3,860 .

The results of the normality test show that the significance value of Asymp. Sig. (2-tailed) of 0.075 (0.075>0.05) that the regression model is normally distributed. Multicollinearity test results show that the tolerance value of the Good Government Governance (GGG) variable is 0.689 , the tolerance value of the intellectual intelligence variable is 0.773 , the tolerance value of the emotional intelligence variable is 0.510 , and the tolerance value of the spiritual intelligence variable is 0.559 is greater than $0,1(10 \%)$. The VIF value of the Good Government Governance (GGG) variable is 1,452 , the VIF value of the intellectual intelligence variable is 1,294 , the VIF value of the emotional intelligence variable is 1,961 , and the VIF value of spiritual intelligence is 1,789 is less than 10 , so it can be concluded that no there are symptoms of multicollinearity between independent variables.

Heteroscedasticity test results showed that the significance level of all variables was above 0.05 . This shows that the regression model is free of heteroscedasticity problems.

The following results of multiple linear regression tests can be seen in Table 2.

Table 2

Multiple linear regression results

\begin{tabular}{|c|c|c|c|c|c|}
\hline \multirow[t]{2}{*}{ Model } & \multicolumn{2}{|c|}{$\begin{array}{c}\text { Unstandardized } \\
\text { Coefficients }\end{array}$} & \multirow{2}{*}{$\begin{array}{l}\text { Standardized } \\
\text { Coefficients } \\
\text { Beta }\end{array}$} & \multirow[t]{2}{*}{$T$} & \multirow[t]{2}{*}{ Sig. } \\
\hline & $\mathrm{B}$ & Std. Error & & & \\
\hline (Constant) & 6,289 & 2,931 & & 2,146 & 0,033 \\
\hline Good Government Governance $\left(\mathrm{X}_{1}\right)$ & 0,122 & 0,045 & 0,166 & 2,702 & 0,007 \\
\hline Intellectual Intelligence $\left(\mathrm{X}_{2}\right)$ & 0,444 & 0,078 & 0,329 & 5,675 & ), 000 \\
\hline Emotional Intelligence $\left(\mathrm{X}_{3}\right)$ & 0,163 & 0,062 & 0,189 & 2,643 & ), 009 \\
\hline Spiritual Intelligence $\left(\mathrm{X}_{4}\right)$ & 0,163 & 0,110 & 0,164 & 2,398 & ),017 \\
\hline Adjusted $R^{2}$ & 0,403 & & & & \\
\hline $\mathrm{F}$ value & 39,722 & & & & \\
\hline Sig. F & 0,000 & & & & \\
\hline
\end{tabular}

Secondary Data, 2019

Based on the results from Table 2 the following equation below:

$$
\mathrm{Y}=6,289+0,122 \mathrm{X}_{1}+0,444 \mathrm{X}_{2}+0,163 \mathrm{X}_{3}+0,163 \mathrm{X}_{4}+\varepsilon
$$

The constant value of 6.289 indicates that if the variable Good Government Governance (X1), Intellectual Intelligence (X2), Emotional Intelligence (X3) and Spiritual Intelligence (X4) are constant, then the managerial performance variable of village government management $(\mathrm{Y})$ has a positive value of 6.289. Good Government Governance (X1) has a coefficient value of 0.122 . This illustrates that each increase in one unit of variable Good Government Governance (X1) can increase the managerial performance of village government management (Y) by 0.122 assuming the other independent variables are fixed or constant. Intellectual Intelligence (X2) has a coefficient value of 0.444 ,

Putri, I. G. A. M. A. D., \& Wirawati, N. G. P. (2020). Implementation of good government governance, intellectual intelligence, emotional, and spiritual intelligence in managerial performance of village government management. International Research Journal of Management, IT and Social Sciences, 7(1), 169-176. https://doi.org/10.21744/irjmis.v7n1.831 
this illustrates that each increase of one unit of intellectual intelligence variable (X2) can increase the managerial performance value of village government management $(\mathrm{Y})$ by 0.444 assuming the other independent variables are fixed. Emotional Intelligence (X3) has a coefficient value of 0.163, illustrating that each increase of one emotional intelligence unit (X3) can increase the managerial performance value of village government management (Y) by 0.444 assuming the other independent variables are fixed.

Spiritual Intelligence (X4) has a coefficient value of 0.163 , illustrating that each increase of one spiritual intelligence unit (X4) can increase the managerial performance value of village government management (Y) by 0.444 assuming the other independent variables are fixed. The results of the coefficient of determination show that the adjusted value R2 $=0.403$, this means that the four independent variables (Good Government Governance, intellectual intelligence, emotional intelligence, and spiritual intelligence) contribute an influence of 40.3 percent to the dependent variable, namely managerial performance of village government management and the rest equal to 59.7 percent is influenced by other variables not included in the research model. F test results show that the calculated $\mathrm{F}$ value for the dependent variable managerial performance of village government management amounted to 39,722 significance of $F$ $=0,000$. Significance value $F=0,000$ (sig. $F<0.05$ ) indicates the significance of the influence of independent variables on the independent variables and the research model is feasible. These results give the meaning that the variables of Good Government Governance, intellectual, emotional and spiritual intelligence are able to predict or explain the phenomenon of managerial performance of village government management.

Based on Table 2, the results of testing the first hypothesis (H1) regarding the effect of Good Government Governance (GGG) on the managerial performance of village government management show a significance value of 0.007 which is less than the value of $\alpha=0.05$. Therefore, the first hypothesis in this study was accepted. This shows that the application of good government governance has a positive effect on the managerial performance of village government management in Badung Regency. The higher the implementation of good government governance, the managerial performance of village government management in Badung Regency is also getting higher. The results of this study are also supported by research by Putri (2012), which concluded that Good Corporate Governance (GCG) will be a supporting factor for achieving good performance. Based on Table 2, the results of the second hypothesis testing regarding the effect of intellectual intelligence on managerial performance of village government management show a significance value of 0,000 less than $\alpha=0.05$ The second hypothesis in this study is accepted, this shows that intellectual intelligence has a positive effect on managerial performance of village government management in Badung Regency. The higher the intellectual intelligence, the managerial performance of village government management will also be higher. The results of this study are supported by research by Fabiola (2005), which shows that intellectual intelligence has a very important role in improving performance

Based on Table 2, the results of testing the third hypothesis regarding the influence of emotional intelligence on the managerial performance of village government management shows a significance value of 0.009 less than $\alpha=0.05$. The third hypothesis in this study was accepted, this shows that emotional intelligence has a positive effect on the managerial performance of village government management in Badung Regency. The higher the emotional intelligence, the managerial performance of village government organizers is also higher. The results of this study are also supported by research by Yenti \& Machasin (2014), which shows the influence of emotional intelligence on employee performance at R.S Pekan Baru that significantly influences employee performance at R.S Pekan Baru. Based on table 2, the results of the fourth hypothesis testing regarding the effect of spiritual intelligence on the managerial performance of village government management show a significance value of 0.017 less than $\alpha=0.05$. The fourth hypothesis in this study was accepted, this shows that spiritual intelligence has a positive effect on the managerial performance of village government management in Badung Regency. Spiritual intelligence is higher, the managerial performance of village government management is also higher. The results of this study are supported by research conducted by Wiersma (2002), stating that spiritual intelligence influences one's goals in achieving his career in the world of work. Research Farrastama et al. (2019), get the results of the influence of emotional intelligence and spiritual intelligence in a positive and significant impact on employee performance. This is intended to provide confidence in him to encourage and motivate him to be more able to improve the performance he has so that his career can develop more advanced.

\section{Conclusion}

Based on the results of the data analysis and discussion above, the following conclusions can be drawn: 1) Good government governance has a positive effect on the managerial performance of Village Government Management in 
Badung Regency. This means that the application of good governance in realizing good government performance will improve managerial performance. 2) Intellectual intelligence has a positive effect on the managerial performance of Village Government Management in Badung Regency. This means that the better intellectual intelligence possessed, the better managerial performance. 3) Emotional intelligence has a positive effect on the managerial performance of Village Government Management in Badung Regency. This means that emotional intelligence possessed by high village management can improve managerial performance. 4) Spiritual intelligence has a positive effect on the Managerial Performance of Village Government Organizers in Badung Regency. This means that the higher the spiritual intelligence of government management, the better the managerial performance of government management. Suggestions that can be given are that good government governance, intellectual intelligence, emotional intelligence, and spiritual intelligence are driving factors that can improve the performance of government management. So, it is important for the government to implement this in order to improve its performance.

\section{Conflict of interest statement}

The authors declared that they have no competing interests.

Statement of authorship

The authors have a responsibility for the conception and design of the study. The authors have approved the final article.

\section{Acknowledgments}

The authors would like to thank the editor of IRJMIS for their valuable time, support and advice in completing the current study.

Putri, I. G. A. M. A. D., \& Wirawati, N. G. P. (2020). Implementation of good government governance, intellectual intelligence, emotional, and spiritual intelligence in managerial performance of village government management. International Research Journal of Management, IT and Social Sciences, 7(1), 169-176. https://doi.org/10.21744/irjmis.v7n1.831 


\section{References}

Dewi, N. P. R. A., \& Ramantha, I. W. (2019). Effect of conflict and unclear role on auditor performance with emotional quotient as moderating variable. International Journal of Social Sciences and Humanities, 3(3), 50-59. https://doi.org/10.29332/ijssh.v3n3.350

Donaldson, L., \& Davis, J. H. (1991). Stewardship theory or agency theory: CEO governance and shareholder returns. Australian Journal of management, 16(1), 49-64. https://doi.org/10.1177\%2F031289629101600103

Fabiola, M. (2005). Pengaruh Kecerdasan Intelektual, Kecerdasan Emosional, dan Kecerdasan Spiritual Terhadap Kinerja Karyawan di Semarang (Doctoral dissertation, Thesis Jurusan Akuntansi. UNDIP).

Farrastama, D. N., Asmony, T., \& Hermanto, H. (2019). Effect of emotional intelligence on counterproductive work behavior with job stress as an intervening variable. International Journal of Social Sciences and Humanities, 3(1), 14-25. https://doi.org/10.29332/ijssh.v3n1.248

Fimela, U. (2011). Pengaruh Good Governance, Gaya Kepemimpinan, dan Komitmen Organisasi Terhadap Kinerja Sektor Publik.

Hasanah, C. U., \& Suartana, I. W. (2014). Pengaruh Interaksi Motivasi Dan Budaya Organisasi Pada Hubungan Antara Partisipasi Penyusunan Anggaran dengan Senjangan Anggaran. E-Jurnal Akuntansi, 46-62.

Ihsanuddin. (2018, November 21). ICW: Ada 181 Kasus Korupsi Dana Desa Rugikan Negara Rp 40,6 Miliar. Nasional.Kompas.Com. Retrieved from https://nasional.kompas.com/read/2018/11/21/19000481/icw-ada-181kasus-korupsi-dana-desa-rugikan-negara-rp-406-miliar?page=all

Jafridin, N. G. D. (2006). dalam Nugraheni (2014). Pengaruh Kontribusi Kecerdasan Intelektual, Kecerdasan Emosional, dan Kecerdasan Spiritual Dan Kepemimpinan Kepala Sekolah Terhadap Kinerja Guru SD Negri Di Kabupaten Mukomuko.

Lips-Wiersma, M. (2002). The influence of spiritual "meaning-making" on career behavior. Journal of Management Development, 21(7), 497-520. https://doi.org/10.1108/02621710210434638

Mardiasmo. (2004). Akuntansi Sektor Publik. Yogyakarta: Andi.

Mulyadi. (2014). Sistem Akuntansi (Cetakan Ke). Jakarta: Salemba Empat.

Munir, N. (2000). Spiritualitas dan Kinerja. Majalah Manajemen, 124.

Natalia, D. L. (2019). ICW: Kasus Korupsi Dana Desa Terbanyak Sepanjang 2018. Bali.Antaranews.Com. Retrieved from https://bali.antaranews.com/berita/138158/icw-kasus-korupsi-dana-desa-terbanyak-sepanjang-2018

Patton, P. (1998). Kecerdasan Emosional di Tempat Kerja, Ahli Bahasa : Zaini Dahlan. Jakarta: Pustaka Delapan.

Putri, I. A. D. (2012). Peranan Good Corporate Governance dan Budaya terhadap Kinerja Organisasi. Jurnal Ilmiah Akuntansi dan Bisnis.

Riyadi, S., \& Yulianto, A. (2014). Pengaruh Pembiayaan bagi Hasil, Pembiayaan Jual Beli, Financing to Deposit Ratio (FDR) dan Non Performing Financing (NPF) terhadap Profitabilitas Bank Umum Syariah di Indonesia. Accounting Analysis Journal, 3(4). https://doi.org/10.15294/aaj.v3i4.4208

Robbins, S. P., \& Judge, T. A. (2008). Perilaku Organisasi, Buku 2 Edisi Duabelas. Alih bahasa: Diana Angelica. Jakarta: Salemba Empat.

Rosalin, F., \& Kawedar, W. (2011). Faktor-faktor yang Mempengaruhi Keandalan dan Timeliness Pelaporan Keuangan Badan Layanan Umum (Studi pada BLU di Kota Semarang) (Doctoral dissertation, Universitas Diponegoro).

Rubiyanto, R. (2011). Strategi Penelitian Pembelajaran. Surakarta: PSKGJ-UMS.

Undang Undang Republik Indonesia Nomor 6 Tahun 2014 Tentang Desa. (n.d.).

Widasari, K. I., \& Dwija, I. G. A. M. A. Pengaruh Good Governance dan Budaya Organisasi Terhadap Kinerja Manajerial Penyelenggara Pemerintahan Desa di Kabupaten Badung. E-Jurnal Akuntansi, 1308-1334. https://doi.org/10.24843/EJA.2018.v22.i02.p18

Widiani, N. P., Putri, A. M. A. D., Sari, M. M. R., \& Wirajaya, I. G. A. (2019). The effect of love of money and emotional intelligence on employee performance with organizational citizenship behavior as mediating variable. International Research Journal of Engineering, IT \& Scientific Research, 5(1), 39-49. https://doi.org/10.21744/irjeis.v5n1.596

Yanti, N. M. Y. W. A., \& Dwirandra, A. (2019). The effect of profitability in income smoothing practice with good corporate governance and dividend of payout ratio as a moderation variable. International Research Journal of Management, IT and Social Sciences, 6(2), 12-21. https://doi.org/10.21744/irjmis.v6n2.601

Yenti, N. Machasin, 2014. Berjudul Pengaruh Kecerdasan Emosinal, Kecerdasan Intelektual, dan Kecerdasan Spiritual Terhadap Kinerja Karyawan pada RS. Pekan Baru. 